\title{
The philosophy of fire safety engineering in the shaping of civil engineering development
}

\author{
W. WĘGRZYNSSKI ${ }^{1 *}$ and P. SULIK ${ }^{2}$ \\ ${ }^{1}$ Fire Research Department, Building Research Institute (ITB), 1 Filtrowa St., 00-611 Warszawa, Poland \\ ${ }^{2}$ The Main School of Fire Service (SGSP), 52/54 Słowackiego St., 01-629 Warszawa, Poland
}

\begin{abstract}
This paper presents modern application of fire safety engineering (FSE) in the shaping of civil engineering development. Presented scientific achievements of FSE become tools used in typical modern engineering workflow. Experience gained through successful implementations of these solutions is then further crafted into prescriptive laws that shape future fire safety. This diffusion of knowledge is limited by law requirements themselves, technical limitations, and yet unresolved challenges that are still being worked on by the researchers in this field. This paper aims to present the achievements of the FSE discipline that may and should be used by civil engineers and other participants of the building process. Explanations given for the choices of fire safety engineers allow a better understanding of their gravity by representatives of other engineering branches. That way it is possible to build empathy between different engineering disciplines, which may significantly improve both the building design process and safety of the buildings itself. The chosen framework of this paper is Appendix A to EU Construction Products Regulation defining basic goals for a fire safe building, with a possible application of FSE given for each of these goals. The current framework of performance-based FSE is presented in relation to the Polish legal system, with recommendations on how to improve both FSE and civil engineering in the future.
\end{abstract}

Key words: fire safety engineering, fire protection engineering, fire protection, performance-based design, prescriptive codes.

\section{Introduction}

Safety of people in case of a building fire is the focal point of building design. Today we achieve this safety thanks to the rapid growth of fire safety engineering $(\mathrm{FSE})^{\mathrm{a}}$ discipline in the 20 th century. This knowledge is involved in the design process of almost all buildings and infrastructure projects, especially in high-risk industry or critical infrastructure, which is quite an accomplishment for such a young discipline of engineering [1]. Fire safety engineers (FSEs) ${ }^{\mathrm{b}}$ enable amazing structures - regarding both scale and aesthetics - which meet the requirements of fire safety [2] to be built. It is a tough goal, as with the expected lifetime of a building, FSEs are bound to provide safety for future generations. The challenges we face today, together with their solutions, are drastically different from what FSE could provide 20-30 years ago.

Almost every aspect of the building (e.g. architecture, materials, occupancy, etc.) influences its fire safety. To provide the required level of safety, it is not rare that the choices made to improve the fire-related characteristics of the building become the driving force behind the whole design. On the other hand, due to complex connections between various engineering branches [3], the choices made by civil engineers and other

\footnotetext{
${ }^{a}$ Fire safety engineering is a term synonymous with fire protection engineering, or fire engineering. In this paper the first name is used consequently.

${ }^{\mathrm{b}}$ Short form FSE is used as a reference to fire safety engineering, as an engineering discipline, while form FSEs is used as a reference to fire safety engineers.

*e-mail: w.wegrzynski@itb.pl
}

stakeholders who are not FSEs, may unwillingly influence the fire safety. This bidirectional connection requires a systematic, holistic approach to fire safety of a building, which is the essence of the philosophy of modern FSE. A sample of such approach, in the form of a framework for a good cooperation between fire experts and structural engineers, was presented by Abramowicz and Kowalski in [4].

Despite strict regulations and advanced design methodologies, supertall buildings or large road tunnels that can be considered the pinnacle of modern engineering are still the scene of catastrophic fire incidents. To reach the level of safety in which fires would cause no fatalities and limited damage, urgent problems beyond the quality of the design also have to be resolved, e.g. the slow diffusion of knowledge, the stress on reduction of fire protection cost, and abuse of overcomplicated methodologies, beyond their scope of application.

\section{Fire safety engineering}

2.1. History and origination. One of the first practical uses of FSE took place after Emperor Nero incinerated Rome in $64 \mathrm{AD}$. The rebuilding of the city was done with fire resistant materials, with no common walls between the buildings and with streets widened to limit the spread of the fire [5]. Although tragic in their origins, these simple rules are close to what modern engineering tries to achieve. Despite this lesson, the progress was forgotten until the next great historical fire - the Great Fire of London in 1666, which had triggered the development of professional firefighting, but has not brought 
any major change to the way people build their homes in other places of the globe. The Great Chicago Fire in 1871 had a similar effect, again turning the focus to non-combustible materials, especially terracotta-like. This fire also accelerated the research on fire resistance of structures, which eventually led to emergence of fire testing laboratories and standardized firetesting techniques. Many great fires have occurred since then, each of them triggering a paradigm shift in various fields of FSE, e.g.: San Francisco (1906) and Tokio (1923) post-earthquake fires, King's Cross Station fire (1987), Mont Blanc Tunnel fire (1999) or World Trade Center fires in Towers 1, 2 and 7 (2001) [6].

Beside the progress being fuelled by catastrophic fires, it was the industrial revolution of 19th and 20th century when the first real and sustained advances in the field of FSE was observed. With an economic return of the investment in fire protection being the main objective, early FSE was mostly related to industry and insurance. Nelson [7], quoting dr Bryan, points that the next major change in the profession occurred during the World War II, when the fire safety researchers were mobilized as part of war effort. This effort continued after the war, eventually changing into the FSE as we know it [7]. Since the early days of FSE till today, the discipline has grown into a matured science [2] with a lively community, multiple research centres around the world, dozens of scientific conferences every year, and faculties in many of the world's best technical universities.

The FSE philosophy may be subdivided into two separate design paths: prescriptive-based and performance-based. The prescriptive approach can be considered an application of the general rules or well-known solutions, which, enforced in a new design, provide a previously accepted level of safety in case of a fire. The performance-based engineering focuses on the aims of protection, and crafting solutions fit to meet these aims. Legislators naturally enforce the prescriptive-based design, as it is easier to verify and execute, while engineers naturally lean towards the performance-driven approach - something for which we chose this route of a professional career. There is no single answer to the question of which way is better, but importantly, the best solutions for today's engineering should set the starting point for future regulations.

2.2 Performance-based and prescriptive-based FSE philosophy. The first applications of FSE were performance-engineered and implemented as the new approach to limit the costs of fires in industry. The expected benefits of their use were meant to lower the insurance costs. This concept of use of FSE in risk analysis was the only possibility to promote the early discipline, as although it had not yet matured or been widely accepted, a direct economic relationship between solutions and their effect was noticeable. This changed with the implementation of safety codes in the first half of the 20th century, which standardized the right solutions, necessary to disseminate the newest achievements of FSE among civil engineers, in the state of deficiency of qualified FSEs. With this commonly accepted approach, the FSE could not be implemented directly as a design approach, but was rather a field of science, focused on improving the existing solutions and codes.
Another change happened in the 1970's, when the US General Services Administration and the U.S. National Bureau of Standards jointly developed an event logic diagram that showed alternative ways of achieving building fire safety [8]. This approach, commonly referred to simply as Appendix D, became a fundamental document for describing a risk-informed system approach to designing building fire safety [9]. Since then, multiple frameworks and guidelines were introduced, implementing the concept of risk-based and goal-driven approach to design, which is related to as performance-based FSE. A comprehensive description of the history thereof is presented in [8], and the concept of performance-based design in $[1,10,11]$, and recently in $[12,13]$. In his work published in 2000, Meacham proposed eight fundamental concerns that should be addressed by a comprehensive performance-based framework for fire safety design, which was the base for the development of these methods for the next decades [8]. Since then, we have observed significant progress in each of these fields, but many challenges are still ahead of us. Alvarez et al. determined eight of those challenges [13], which are also an excellent summary of what a true performance-based FSE design should be [13]:

- Applying generic guidance to specific projects

- Defining, using, and quantifying the performance/acceptance criteria

- Selecting design fire scenarios

- Comparing the levels of performance between an engineering solution and a solution based on prescriptive requirements

- Determining the most influential factors affecting the evaluation of trial designs

- Dealing with "idealized" design fire protection measures and "real life" installed and running measures

- Estimating the consequences of design fire scenarios

- When available, adapting literature values for use in models Is there a direct connection between performance-based and prescriptive philosophy of FSE? David J. Thomas [14] claimed that yesterday's performance is today's prescription. This is a very precise description on how matured solutions become the future standards. It also indicates that the prescriptive approach forced by Authorities cannot block the performance solutions, as this essentialy prevents further development of the prescriptive approach. This risk was already stated in 1925 US Building Code [15], as quoted by Czarnecki [3]:

"Wherever possible, the requirements should be formulated in terms of performance, based on the research results referenced to the performance conditions, and not in terms of the material referenced to the components and the method of preparation. Otherwise, any new material or new material systems (new sets of already known materials) that could meet the technical requirements and are satisfactory in economic terms, will encounter barriers that would slow down the technological progress."

2.3. Performance-based design approach in Polish Building Code framework. Polish Building Code [16] and its delegated acts, e.g. [17] or [18], force design solutions through strict and direct requirements. These requirements are not only obligatory, 
but also their implementation and execution are carefully verified (typically by officers of State Fire Service) at both the stages of design acceptance and commissioning. It may seem that in the Polish Building Code system the mechanism of slowing the progress through the strict, prescriptive law works just as explained in the quote above, and for some buildings, derogation seems to be the only way to allow the benefits of the modern state of knowledge. In fact, it is most likely impossible to design a supertall skyscraper or a large-volume shopping mall in Poland by only following the building code. In practice, the derogations became an integral part of the building permit procedure.

Besides the derogation procedure, a notable exception of prescriptive laws within the building code are the regulations on smoke and heat exhaust ventilation (SHEV) systems ( $\$ 270$ [17], App. 1 to [18]), which can be considered fully performance-based. Seven years have passed since the implementation of this performance-based rule, and while it can be associated with liberation of the SHEV design that allowed the design of smoke exhaust systems in challenging and inspiring structures, some issues with this approach have been observed. Many of SHEV system designs, despite using the same tools and "state of the art knowledge," are conceived in an entirely different manner, and the quality of these solutions ranges from untenable to excellent. This diversity in quality of the solutions may be attributed to freedom of assumptions for the design, including fire scenarios. Variability in the size of the fire and smoke production has the biggest influence over the system's performance [19]. Incorrect choices lead to systems with a doubtful performance. Such inconsistencies in design were pointed out as a typical flaw of performance-based approach by Alvarez et al. [13]. Without well-defined scenarios, acceptance criteria, and, most importantly, education of authorities responsible for the acceptance of such solutions, there will always be a possibility of human error or intentional abuse.

A middle ground between the performance and prescriptive engineering can be a system in which performance-driven design is required by setting the goals for the solution, followed by predefined scenarios for which this solution has to be tested. This is how performance-based engineering is implemented in New Zealand. While the country was one of first to fully accept performance-based solutions in the 1990's, this approach was changed to scenario-based in the first decade of the 21 st century through the application of the $\mathrm{C} / \mathrm{VM} 2^{\mathrm{C}}$ verification method. Other possible ways to maintain the quality of the FSE solutions is through additional third-party check of all performance-driven designs - a highly cost- and time-consuming requirement. This can also be done indirectly, by increased responsibility of the engineer over his design (which in a way leads to a voluntary third-party check). The derogation-based way of implementing FSE in Poland fits within this approach. Chartered fire safety experts have to approve solutions before they are submitted, and then qualified personnel of the Ministry of Infrastructure and

\footnotetext{
${ }^{c}$ Verification Method C/VM2 consists of six Building Code clauses related to protecting people in and around buildings, limiting fire spread, and helping the firefight and rescue. https://www.building.govt.nz/building-code-compliance/c-protection-from-fire/
}

Development, often supported by the National Headquarters of State Fire Service and Building Research Institute, has to confirm each alternative solution.

\subsection{Fire safety engineering in CPR framework.}

"Construction works as a whole and in their separate parts must be fit for their intended use, taking into account, in particular, the health and safety of persons involved throughout the life cycle of the works. Subject to normal maintenance, construction works must satisfy these basic requirements for construction works for an economically reasonable working life" [20].

This definition, written in Appendix 1 to Construction Products Regulation (CPR) [20], summarizes the expectations set by law for modern civil engineering, and is followed by a list of basic requirements:

1. Mechanical resistance and stability

2. Safety in case of fire

3. Hygiene, health, and the environment

4. Safety and accessibility in use

5. Protection against noise

6. Energy economy and heat retention

7. Sustainable use of natural resources

Implementation of CPR into Polish law system is done through delegated acts to building code, and the requirements related to fire safety are repeated in $\$ 207$ of [17]:

"The construction works must be designed and built in such a way that in the event of an outbreak of fire:

a) the load-bearing capacity of the construction can be assumed for a specific period of time;

b) the generation and spread of fire and smoke within the construction works are limited;

c) the spread of fire to neighbouring construction works is limited;

d) occupants can leave the construction works or be rescued by other means;

e) the safety of rescue teams is taken into consideration."

In the opinion of the authors, the need to limit the socio-economic cost of the fire also has a strong influence on the civil engineering development. While direct protection of human life is the essential goal, also features related to the quality of life, such as protection of the property, business continuity, preservation of historical value and the environment must be assured [8]. These elements are not directly required by law, but are enforced by the expectations of investors and users of the engineered buildings. In this way, the CPR sets the minimum requirements, which the investors amend with their expectations, and then try to fulfil with minimum cost. To do that, knowledge gathered within FSE discipline must be used, along with its appropriate tools.

\section{Tools of FSE}

Performance-based FSE can rarely be applied as a rule of thumb or by an engineer's judgement. A simplified approach usually leads to either an overdesign with unnecessary safety margins 
or to an underdesign that may be unsafe, but rarely to a cost-effective solution. To provide solutions that would exceed the prescriptive-based recommendations, FSE has developed a wide scope of tools used in practice for the solution to fit the project.

3.1. History of fire modelling tools. In the 1950's and 1960's various models were developed to better understand the physics of fire and its consequences, and, among others, the works of Thomas, Yokoi or Kawagoe has to be mentioned [21-23]. A paradigm shift in this field happened in the 1970's with the introduction of zone fire models, of which the ones of most importance were the RUNF, the Harvard model, and the Consolidated Model of Fire and Smoke Transport [7, 24]. These models allowed for the estimation of temperature in compartment fires, along with some basic performance of SHEV systems, estimation of actuation time of sprinklers or sensors, and quantitative assessment of the influence of fire products on the users of the building. The origination of zone models comes from fulland small-scale experiments, and as such, these solutions are probably the most validated tools of FSE. Zone models are still developed today [25-27], although they are less popular than CFD models.

Another significant shift in the discipline came with the introduction of a method for quantification of fire safety in a building by estimating the available safe evacuation time (ASET), proposed by dr Cooper in the 1980s [28]. This concept is still the common approach to the estimation of fire safety related to human evacuation in the buildings.

The pinnacle of FSE tools is the numerical methods, such as computational fluid dynamics (CFD), finite volume methods (FVM), and finite element methods (FEM), which allow the simulation of complex physical phenomena in any geometry and with great accuracy. Due to their complex nature, they are very prone to the user's mistake [29]. Estimation of this error was possible through round-robin comparison studies, carried prior to, and after extensive fire experiments, out of which the most important one was the Dalmarock fire experiment [30, 31]. The results of these studies show that even with detailed information about the parameters of a fire (obtained through an experiment), predictions of the outcome have error ranging from
$20 \%$ to $200 \%$, along with high inconsistency between various FPEs who performed the analysis. In the a priori approach, without reference values for the heat release rate parameter, these inconsistencies were even bigger.

An important step for performance-based FSE was the introduction of a CFD model called Fire Dynamics Simulator (FDS) [32], by the National Institute of Standards and Technology (USA), in collaboration with VTT (Finland). With its introduction, the community gained a highly optimized, fire-oriented numerical model, that helped the further growth of the discipline in almost all areas. Along with the implementation of FDS in FPE, an enormous effort was put to validate it, along with other free and commercially available CFD tools used in FSE, e.g. OpenFoam [33], Ansys Fluent [34], Phoenics [35], Smartfire [36] or StarCCM+ [37], etc. This effort is continued to build a broad database of validation studies which can help assess the inconsistency of the simulation results between models and their users [38]. Some of the advanced applications of this method, related to various areas of FSE can be found in [39-42].

3.2. Problems connected with the use of FSE tools. The common and easy access to advanced numerical models employing computational fluid dynamics, along with the availability of cheap, high-computational-power computers or cloud services caused a significant rise in the popularity of commercial CFD simulations in the design process. While simple "hand calculation" models were developed through experiments, are well-validated and appropriate for the purpose of design, CFD often is chosen over, as a "more credible" tool, or by assumption that it has a greater chance to be accepted by authorities over a simple method [43]. Since this high-resource-consuming process may often lead to lower quality of solutions, this may be considered a regression of the development.

A typical workflow for fire engineers using fire models in a building design process should begin with an initial assessment using the simplest applicable method, followed by gradual progression to more complex methods if necessary or justified by the project, Fig. 1. This is often replaced with an application of personal judgement or golden rules, followed by confirma-

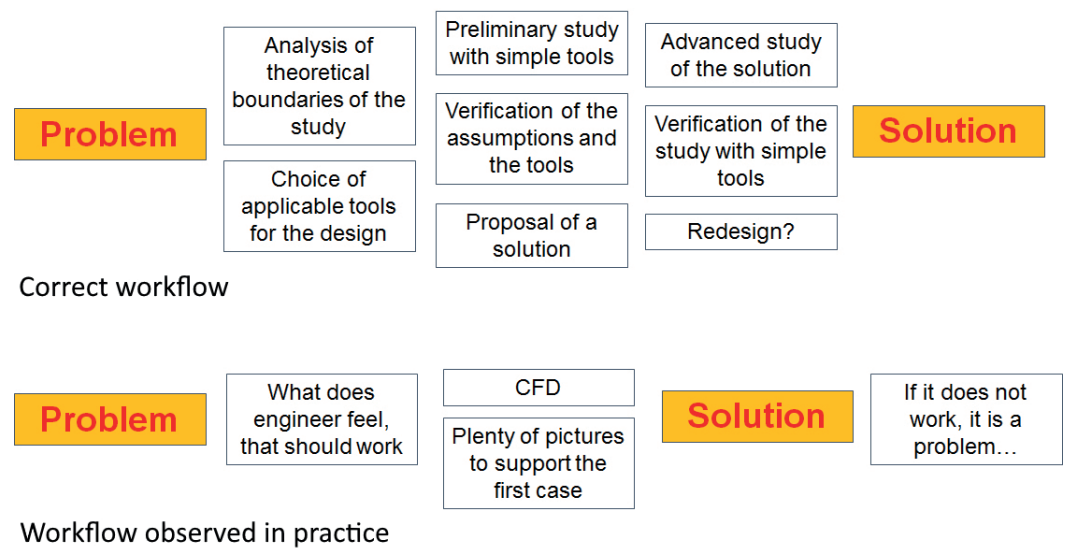

Fig. 1. Example of engineering workflow in fire safety engineering, expected (top) and observed in practice (bottom) [39] 
tion with numerical modelling - such workflow generates major issues if the solution does not work, as tools to fix it are limited.

A guideline to tools used in performance-based FSE is given in [44], and valuable information on model applicability can be found in $[43,45,46]$. Sample choice of practical tools for given problems in the design of an industrial building is presented in Table 1 [39].

Table 1

Fire safety engineering tools used in design process - referring to industrial/storage facilities design [39]

\begin{tabular}{|c|c|c|}
\hline Type & Software / model & Application \\
\hline CFD & $\begin{array}{l}\text { FDS, ANSYS, } \\
\text { Phoenics, Jasmine, } \\
\text { Star-CCM+, } \\
\text { Smartfire, } \\
\text { OpenFoam }\end{array}$ & $\begin{array}{l}\text { CFD analysis forms the } \\
\text { base of most of SHEV } \\
\text { design, and is widely } \\
\text { used in the evaluation of } \\
\text { environmental conditions } \\
\text { for users. }\end{array}$ \\
\hline Evacuation & $\begin{array}{l}\text { Pathfinder, Evac, } \\
\text { buildingExodus }\end{array}$ & $\begin{array}{l}\text { Usually combined with } \\
\text { CFD analysis as the } \\
\text { method for estimation of } \\
\text { RSET }\end{array}$ \\
\hline \multirow{4}{*}{$\begin{array}{l}\text { Hand } \\
\text { calculations }\end{array}$} & Fire load density & $\begin{array}{l}\text { Requirements for industrial } \\
\text { buildings rely on fire load } \\
\text { density. Thus, this element } \\
\text { is part of every industrial } \\
\text { design. }\end{array}$ \\
\hline & Explosion risk & $\begin{array}{l}\text { Risk of explosion will } \\
\text { increase the requirements } \\
\text { for the building. }\end{array}$ \\
\hline & $\begin{array}{l}\text { SHEVS: } \\
\text { NFPA, CEN, } \\
\text { DIN, TR, } \\
\text { fireplatform.eu }\end{array}$ & $\begin{array}{l}\text { Hand calculations are } \\
\text { always part of the SHEV's } \\
\text { design, and are often } \\
\text { the only dimensioning } \\
\text { approach used. }\end{array}$ \\
\hline & RTI calculations & $\begin{array}{l}\text { Used in the assessment of } \\
\text { sprinkler/vent interaction } \\
\text { and sizing of the design } \\
\text { fire. }\end{array}$ \\
\hline $\begin{array}{l}\text { Zone Fire } \\
\text { Models }\end{array}$ & $\begin{array}{l}\text { CFAST, Brisk, } \\
\text { fireplatform.eu }\end{array}$ & $\begin{array}{l}\text { Used in some preliminary } \\
\text { design, rarely part of the } \\
\text { building design permit } \\
\text { application. }\end{array}$ \\
\hline $\begin{array}{l}\text { Radiation } \\
\text { modelling }\end{array}$ & $\begin{array}{l}\text { fireplatform.eu, } \\
\text { FDS, ANSYS }\end{array}$ & $\begin{array}{l}\text { Used in the derogation } \\
\text { process for the possible } \\
\text { separation between the } \\
\text { buildings, may be used for } \\
\text { the design of separation } \\
\text { between storage areas in } \\
\text { a storage facility. }\end{array}$ \\
\hline FEM/FVM & ANSYS, Robot & $\begin{array}{l}\text { Used in structural design } \\
\text { of some buildings for fire } \\
\text { conditions. }\end{array}$ \\
\hline
\end{tabular}

\section{Areas of FSE related to CPR requirements}

4.1. Structures in the fire. "(a) the load-bearing capacity of the construction can be assumed for a specific period" [20].

Effects of fires on structures were among the most investigated aspect of FSE throughout the world, although the main progress was gained through full-scale testing, rather than simulations. Quoting Nelson [7], the first practical models of structural response to fire were introduced in 1942 in the appendix to document BMS 92, and the first analogue methods for determining fire resistance of structures were developed in the 1950's.

The most common way to test structures in fire is to use the standard time-temperature curve (also known as ASTM E119) - whose first publication dates to 1916 [47]. This test does not present the characteristics of a structure in realistic parametric or localized fire scenarios. While the parametric description of a fire may be a natural way to describe this phenomenon by FSEs, the standard time-temperature curve approach is better understood by everyone else. Although authors expect a paradigm shift in this field, due to the introduction of travelling fires theory and wider use of parametric fires [48-50], the standard time-temperature curve will most likely remain a staple reference tool for estimation of structural resistance to fire.

The FSE shapes the civil engineering development in this field by allowing cheaper and lighter structures to withstand the fire for an equal duration, due to better materials and techniques. Application of performance-driven approach coupled with risk analysis of fire scenarios may allow for a substantial optimization of the structure, compared to the traditional, prescriptive-based approach, even though this must be a part of a derogation.

Both Appendix 1 to CPR [20] and §207 of [17] state that the building should have the load-bearing capacity of construction for a given period, yet the time itself is not defined in the legislative framework. It is a vital question - is the required time the time to evacuate, time for the rescue operations, or maybe the total duration of a fire, including the cooldown phase? With the lack of direct requirements in the law, there are attempts to interpret this based on the need of the moment.

The most important reference documents related to fire performance of structures are Eurocodes; general requirements can be found in Eurocode 0 [51] and 1-2 [52]. The requirements for a structure in a fire in Polish legislative framework are placed in $\$ 216$ of [17] that relates the resistance of the structure to fire to basic characteristics: resistance (R), insulation (I), and integrity (E), which can be measured in laboratories with relation to time. This is a safe route which leads to a high level of fire safety. It must be noted that in structural engineering the fire is treated as another load - which means that sometimes, the structure itself may withstand the fire without any additional means. In this case, to upgrade the structure with a passive fire protection may seem like a waste of resources. However, in some cases, engineering solutions have different vulnerability and have to be individually protected at various levels. A good example are CFRP-strengthened RC structures that require strong insulation, while the structure that they reinforce may not need any [53]. Development of FSE in the field of structural engineering can 
be considered rapid, and its effects regarding how structural engineers can better optimize the fire safety of their structures, are highly anticipated.

4.2. The spread of fire and smoke within the building. "(b) the generation and spread of fire and smoke within the construction works are limited" [20].

The second requirement of CPR [20] relates to multiple aspects of FSE, such as flammability and smoke production of building materials, compartmentation of the building, active fire protection (e.g. through sprinkler systems), and also the smoke and heat exhaust ventilation (SHEV). All of these features, except for SHEV, are prescribed in the law with basic requirements, usually put in the form of indexes and ratings. The implementation of FSE to these solutions is similar to what the discipline was in the 1950s and 1960s - a science-based improvement of technical solutions available in this field to provide higher ratings with lower cost.

As opposite to all other systems - the design process of SHEV systems can be considered fully performance-based. It is required by law ( $\$ 270$ of [17]) that the system provides a sufficiently clean of smoke egress path, in time needed for the evacuation of people, along with a supply of air that matches the amount which is exhausted. This simple rule connects the requirement (b) to requirement (d) of CPR [20]. To measure if the system meets these requirements, the engineer should perform additional analyses - typically, a numerical analysis of smoke and heat spread within the building, with the use of computational fluid dynamics tools, along with the estimation of expected evacuation time for a similar fire scenario [54]. Some FSEs consider that the requirement of $\$ 270$ is met when the system is designed to the standards prepared by NFPA or CEN. While this may be true for simple architecture, effects connected with the flow of smoke in a complex architecture may render the recommendations of such standards useless, and such systems require a personal verification [55].

The problem with this approach is that merely simulating a fire cannot be considered engineering - it is just modelling [2]. Simulation is no more than a tool, no matter how complex the solver is. To fully perform an FPE analysis of an SHEV system, the process must also consist of the choice of design fire scenario, risk analysis, choice of solver applicable for the problem (along with physical sub-models), post-processing of the results and the final selection of the design $[29,56]$. Each of these steps is widely described in the literature, with the selection of the design scenario often being considered as the most important choice of the whole design process. More information about this choice and the modern FSE tools related to it is provided in chapter 5 .

In the area of limiting the spread of fire and smoke, FSE provides civil engineers with a variety of well-described technical solutions and active systems that may be used to lower the risk of fire within a building. Additionally, as a part of a derogation procedure, these solutions may lead to lowering prescriptive requirements for the building or be used as an alternative fire safety strategy - resulting in a free-of-constraints development of a new facility.
4.3. External spread of fire. "(c) the spread of fire to neighbouring construction works is limited" [20].

The Polish law limits the choices connected to the spread of fire to neighbouring construction works to a form of a distance matrix, based on simple design choices, but in many countries, this choice is a subject of performance-based FSE analysis. To solve issues with distances between buildings, complex tools are used to estimate the heat radiated from the fire towards neighbouring structures [57]. In Poland, a similar approach may only be used as a derogation from the requirements of law. In such case, additional features are implemented (e.g. water curtains, fire curtains) to ensure the same level of safety as provided by the generic separation distance.

The third requirement also relates to the spread of fire through external partitions of a building [58]. Facade fire of The Address Hotel in Dubai dominated the media coverage of 2016 New Year's Eve, placing this field of knowledge in the focal point of interest of FSEs, Fig. 2. In the following months, three other supertall buildings in the Middle East were a scene of major fires, which spread rapidly through the building facade. Such fires are especially difficult to contain, as the rapid spread beyond the compartment of origination is something violating the unspoken golden rule of the design of various fire protection tools - "one fire in one fire compartment, at the same time." As the typical active systems fail in this field, the solutions provided by FSE range from improved material properties, through technical solutions of how facade systems are built, to the independent active protection of external partitions.

Through the newest achievements of civil engineering, materials such as cross-laminated timber, wood processing by-products or recycled plastics are introduced into buildings. These combustible materials increase the risk of an external fire growth. Other challenges regarding the external fires arise with the popularity of solar panels built on the walls and roofs of buildings. Along with the sustainable energy sources, large domestic energy storage devices are introduced, usually in the form of large-scale Li-ion batteries which are also troublesome from the FSE point of view. If FSE cannot overcome these

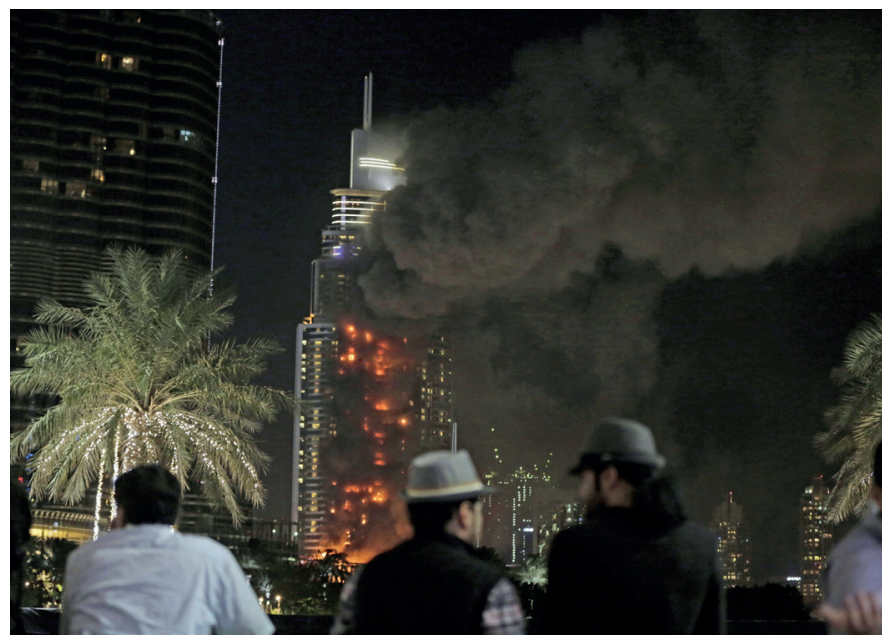

Fig. 2. The Address Hotel fire on 31.12.2015, Source: Wikipedia Commons, Author: Bling Bling Gold, under CC-BY-SA 4.0 license 
challenges, such solutions will not become common, as the socio-economic cost of large fires is too high for civil engineers, and they will be unwilling to take the risk.

4.4. Evacuation. "(d) occupants can leave the construction works or be rescued by other means" [20].

The fourth requirement deals with the most random element of fire safety in the building - its occupants. While, after fire and smoke spread models, the evacuation modelling is the most matured field of FSE, numerous assumptions that need to be made by FSEs in the process make the tool complicated and arduous in practical use. A review of available evacuation models and a general description of the modelling process can be found in $[46,59]$.

In Polish legislative framework, the building features related to evacuation, such as the number and size of stairwells, the length of corridors and width of doors are all prescribed by law, based on the number of occupants and the type of the building. The occupant count is also prescribed in the form of coefficients per square meter of the floor, and stated in the law [17] (unless a number of users relate to the occupation - e.g. in theatres or cinemas). Although we have excellent tools to investigate the flow of evacuees in the building, these tools are rarely used in the development of optimal evacuation paths in the building, with a notable exception of large sports arenas [60]. The last part of the requirement - "(...) or be rescued by other means" indicates a possibility of providing a fire-safe area within the building, but requirements for such are not provided in the law.

The evacuation modelling can be sub-divided into two separate fields: movement of people and behaviour of individuals. First of them involves a description on how masses of people move through various pathways and how streams of occupants mix. The result of these studies is usually the walking speed of occupants or the capacity of exits and pathways. As it is possible to quantify the physical capabilities of people, there are multiple studies over these phenomena, e.g. [61, 62], along with mathematical models that use this knowledge for the estimation of the movement of people.

The second field of evacuation modelling, quoting Carattin, "behavioural science, is fundamentally more complex and uncertain than standard engineering" [63]. It is not possible to precisely estimate the future behaviour of people with only historical data and mathematical modelling - and the best proof for this claim is that stock markets still exists and are not dominated by scientists. The behavioural experiments are usually explanatory, but not predictive - which means that the result of modelling may be entirely different from what happens during a real fire [64]. Despite this, we need basic data that can become the boundary condition for our modelling. This leads to cases in which our idealized description of human behaviour in fire differs too much from the real world. Great examples are the use of escalators or evacuation by car in case of fire, both of which considered prohibited during an FSE analysis, while being commonly observed in real evacuation footage. While it may not be the best solution, we do not currently have a better one. In the end, "it is better to be roughly right, than precisely wrong" [3].
In an engineering practice, the most common use of evacuation modelling is through the available and required safe egress time concepts (ASET, RSET) [65]. These concepts play a key role in the quantification of the level of safety in a building. By assumption, if users of the building have more time to leave the premise (RSET) than it takes for the environment to become untenable (ASET), the building may be considered safe for occupants. This rule is the foundation of the design of many safety features, such as SHEV systems or compartmentation of the building. Assessment of the time available to occupants is done through CFD modelling, while the estimation of the time required to leave the building is obtained through an evacuation study. This estimation requires knowledge of the time necessary to detect a fire, alert the people, the time needed for people to make a decision to evacuate and finally, the total time of movement through the building. As mentioned before, with a lack of credible behavioural data for the assessed group of occupants, the assumptions are based on engineering standards, e.g. [66].

4.5. Rescue operations. "(e) the safety of rescue teams is taken into consideration" [20]

This requirement is not enforced directly like the other, that is either by a prescriptive requirement or a performance goal to achieve. The only general review of the rescue operation safety takes place during the SHEV system design. Firefighters' safety must be addressed if the designers lower the temperature class of the smoke extraction fans. Even in this approach, same problems arise as with the safety of occupants - there is a lack of predefined scenarios and acceptance criteria.

In the Polish law framework, the laws that are the basis for firefighting operations - fire routes, water supply, etc. - are outside of the building code, but building code requires that all of the buildings are compliant with them. Although FSE shows progress in this field $[67,68]$, the state of the art knowledge regarding firefighting technique and solutions is rarely implemented in practice in civil engineering design.

\section{Performance-based design}

5.1. Good practice in performance-based design. FSE has adopted performance-based design as an alternative approach to providing safety in buildings. However, its implementation has drifted towards the concept of unquantified level of safety which is 'equivalent' to the code, rather than towards the accurate, engineering-based performance assessment [6]. Complete performance-based design should solve the problems described in Chapter 4 for carefully chosen design scenarios (Chapter 5.2) in a full and a holistic way (Chapter 5.3). To perform this task correctly, the engineer should relate to good practice guidelines, from which the most comprehensive is the SFPE Engineering Guide to Performance-Based Fire Protection [69], and the more recent [70]. When using complex tools of FSE, such as these described in chapter 3, the designer should relate to relevant guidelines [44] and other methods to verify their scope of applicability [43]. To assess the performance of the solution, it is necessary to know the limits of structural damage caused 
by a fire, and the effects of fire and smoke on humans. For structures, limit states design (LSD) method is used. LSD is subdivided into the ultimate limit state and the serviceability limit state, which should be related to design situations which also include accidental design situation - a fire. In Poland, this method is enforced by Eurocode [51]. For the effects of fire and smoke on humans, there are various guidelines, of which the most recent are gathered in relevant chapters of SFPE Handbook of Fire Protection Engineering [71-73].

5.2. Design fires and fire scenarios. To estimate the safety of the occupants, FSEs craft design fires and fire scenarios that are a representation of the worst fire that may happen within the building. Based on the fire scenarios, various protection strategies, referred to as trial designs, may be investigated, resulting in a final choice of the combination of safety features that gave the best results (and sometimes the one that is most cost-effective for a given problem). Alvarez et al. well describes the difficulty of the choice of the worst credible fire [13], citing the OECD Committee on the Safety of Nuclear Installations (CSNI): "not all large nuclear power plant fires are significant from a public safety point of view, nor are all safety-significant fires large" This means, that the design scenario shall be a product of engineering connected to the building, and not just a general assumption for a given type of occupancy. An example of a complex choice of fire scenarios can be presented for the design of a tensile roof structure of a large sports arena in Poland, Fig. 3 [74]. Four design fires were chosen:

- A $-25 \mathrm{MW}$, fast growing fire of the stage in the central point of the arena (lowest point of the tensile roof) - critical for the structure and SHEV design;

- B - 12.5 MW, fast growing fire of a trade stand in the smallest SHEV zone, directly next to an air inlet - critical for the SHEV design;

- $\mathrm{C}-2.5 \mathrm{MW}$, medium growing fire at the highest level of seats - critical for the evacuation of people at the top of the arena;

- D - 7.25 MW fire of the "video-cube" - critical for the structure.

Each of these fires represented a different threat to the building and its occupants, and each of them was critical for at least one aspect of the analysis.

While an engineered design scenario approach is widely used, even the best expert judgement cannot foresee everything.

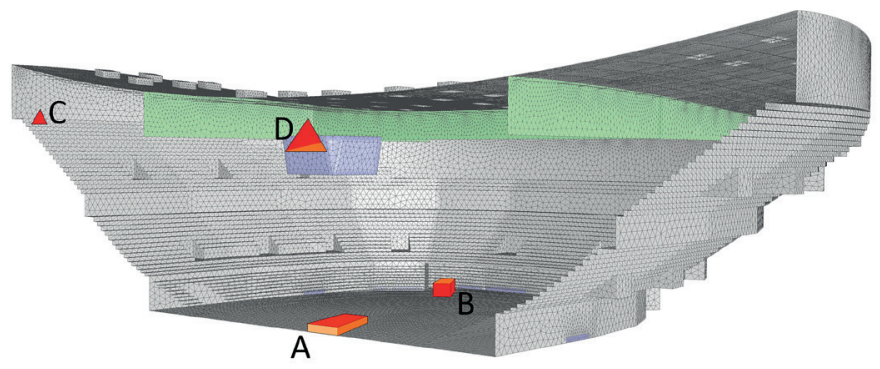

Fig. 3. Fire scenarios for the design of tensile roof structure of sports arena $[74]$
Short after commissioning one of the sports arenas in Poland, it was a host of a Bus and Tram trade show, with eight large vehicles placed inside - a fire risk that would not be expected in such a building. Due to the engineers' natural limitations, it may be beneficial to use more advanced FSE tools in the design scenario process - simple probabilistic methods, such as event trees [12], Monte Carlo scenario modelling [75], or fractional factorial design approach $[76,77]$. Some of these tools are already being implemented within previously described zone models [78] or CFD codes [75]. With probabilistic tools and improved fire models, FSEs can investigate more specific events and scenarios which are a better representation of a probable fire in a building. This allows for the crafting solutions to better fit the building, often leading to a decrease of previous safety margins.

An overview of commonly used design fires and design scenarios can be found in $[79,80]$.

5.3. Holistic design. Fire safety is an outcome of multiple characteristics of the building (architecture, compartmentation, materials, occupancy), along with passive and active tools of fire protection. Acknowledgement of interactions between these features, along with the influence of other engineering branches on the fire safety of the building may be referred to as total, or holistic approach to FSE. For such an approach, both qualitative and quantitative approach to modelling fire safety performance is required [81]. Framework for such approach, with an intention to be used by fire service officers as a tool supporting their decisions, was presented in $[82,83]$. This analysis gives a deeper view on the performance of the building, with a more conscious choice of solutions, and a better overview of the design process [84]. Such approach cannot work with a prescriptive law - by default, all elements of the system are taken into consideration, and because of that, the prescriptive requirements may render the most optimal solution as non-compliant with the law. On the other hand, even in Polish law framework such approach may be used as an additional source of knowledge in the design process, e.g. in determining optimal exit signage locations or fire related scenarios.

While the FSEs are the ones who understand the impact of various changes on fire safety during the design process, there are more parties involved in it: investor, architect, constructors, installation engineers, interior designers, authorities, commissioners, insurance companies, administration, and the end user of the building. Many critical decisions, which in other professions would be reserved for professional engineers, are made by non-engineers or engineers without a background in FSE, using various codes and standards instead of engineering analysis [7]. Backing up a decision with "that is a fire requirement" may be enough to enforce a design choice, but its understanding is required to make the solution work. The most obvious example of such a problem is the common misuse of self-closing devices for fire doors. FSEs acknowledge these devices as the most cost-effective tool to limit the risk of fire in a building, while most of the users will just block them as an annoying feature incompatible with their intended use of the building. This problem was also pointed out by Alvarez 
[12] in the introduction to risk-informed, performance-based FSE framework. In the opinion of the authors, if users realized how important a feature is for their safety, they probably would change their mind about disrupting it. The tools of FSE can bring a great help in showcasing the difference between good and bad with regards to fire safety and the consequences of misuse of a device.

The implementation of the holistic approach to the total fire safety of a building may also face another problem - the engineers sometimes fail to acknowledge that the solution may be used in a different way than they expect it to be. Things like well-maintained automatic fire detection or unblocked fire separation gates are taken for granted as the "responsibility of the administrator." While this is true, the engineer should acknowledge that the weakest component in any engineering system is the human - one that may continuously disrupt the alarm system by deleting the "another false alarm signal" or one that will unintentionally block a fireproof gate. This is why robustness scenarios should be implemented. Such fire scenarios are used to find what risk is connected to the failure of one critical part of a system - e.g. how will SHEV system operate if there is a failure of the sprinkler system and the fire is not contained. This approach can help find and eliminate the weak points of a solution.

\section{Role of fire testing laboratories in FSE}

Accredited fire testing laboratories play a major part in the shaping of the development of civil engineering [85], Fig. 4. The most obvious role of the laboratory is in the initial product testing - a complex evaluation of whether the products or materials meet their requirements stated in prescriptive acts of law. This is an essential part of the certification of products, which in the end allows them to be used in construction. Such testing also allows the manufacturers to verify their solutions

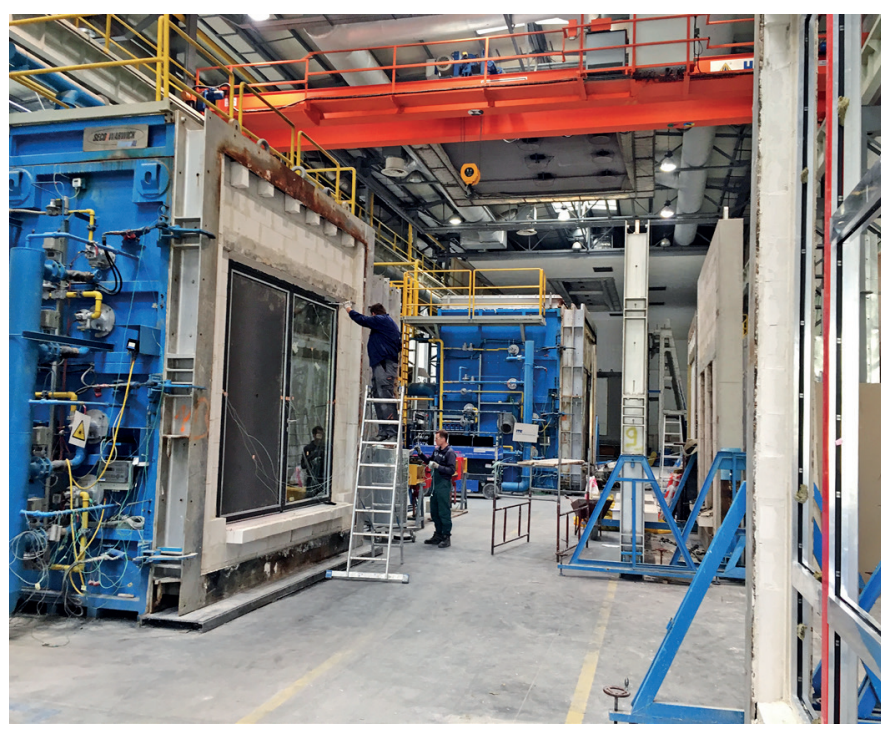

Fig. 4. Large furnaces hall in the Fire Testing Laboratory of Building Research Institute, Pionki

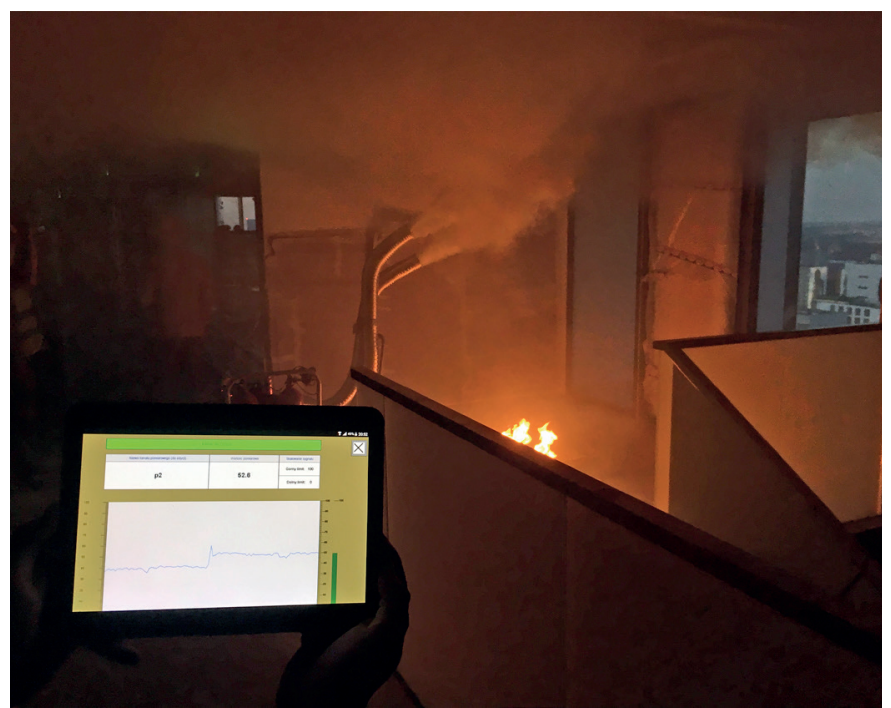

Fig. 5. Dynamic measurements of pressure differential system, combined with a hot smoke commissioning test in a high-rise building - a site acceptance testing method developed in Fire Testing Laboratory

against large-scale fire, which is a vital part of product development. As mentioned in chapter 4, in a highly rigid legislative framework, evolution of solutions and materials to meet higher rankings and requirements is the most basic form of progress in the construction industry. New advancements in materials, products and techniques heavily influence how buildings are designed and built. Besides the basic function as the evaluator, fire testing laboratories take part in market surveillance. In this process, products (e.g. fire doors, insulation materials) are purchased on the market, and then their characteristics are estimated. This process ensures that the products available on the market are the same, as they were tested during their approval and certification phase. A similar process is sometimes observed in the construction of critical infrastructure. Randomly chosen samples of products may be tested in a fire testing laboratory, before the whole batch of products is installed in the building.

Fire testing laboratories play a role in education, as a place where FSEs can gain first-hand knowledge on how materials, elements, and structures act in case of a fire. Practical experience on how construction products act in high temperatures, which is generally unavailable to other participants of the building process, often plays a vital role in avoiding potential issues or finding solutions for the existing problems. This knowledge, being treasured, is rarely shared. Usually, it is presented in seminars hosted by EGOLF or by the laboratories themselves, only to a limited number of recipients. It would be valuable for the FSE discipline and civil engineering development if this trend could be changed, and sharing of experience between fire laboratory experts and FSEs occurred in a more open way.

Finally, the laboratories take part in the development of new standards (both national and European) and requirements. New tests and commissioning methods are introduced, e.g. [86], Fig. 5, to allow the evaluation of product characteristics written 
in the acts of law. At the same time, new requirements are recommended to authorities, based on the practical experience in the field of fire testing, which helps improve the general level of fire safety introduced through the prescriptive-based law.

\section{Conclusions}

Fire safety engineering is shaping the civil engineering development, often being the driving force behind the design of critical aspects of buildings. Both design philosophies: prescriptive-based and performance-based are important in this process. By good prescriptive laws, the minimum level of safety is ensured in all new buildings, promoting solutions that meet the building code requirements in a most cost-effective way. Performance-driven design, while not being allowed by the Polish law in a straightforward manner, is key to the development of the whole discipline and is the most important approach in the design of cutting-edge civil engineering projects. With growing experience and knowledge of the FSEs, we are capable of building bigger, deeper and higher, while maintaining the same high level of fire safety in a cost-effective manner.

How will FSE shape the civil engineering development in future? In his survey among board members of Fire Technology, a highly respected journal in the field of FSE, Rein asked about the drivers of change in the discipline [87]. Most of his recipients answered that the most important factor is performance-driven design, followed by environmental protection and sustainability, and interface between science and technology. The feelings of the authors are similar; modern research is driving the progress of the modelling tools and performance-based design, which then affects the design solutions included in a design and later in the prescriptive, legislative frameworks. There is a never-ending need to make this route from researchers to practitioners and authorities as short as possible. The diffusion of knowledge is rapid due to the small size of the FSEs community, but this also causes problems with the availability of high-level consultancy. There is also an evident lack of education, especially outside the FSEs - among architects, civil engineers, and other engineering branches. The consequences of choices related to the fire safety made by non-fire-professionals are often unknown to them. It costs much working time and resources to resolve issues caused by a basic lack of knowledge or communication.

Design and architecture of new multipurpose buildings, increased use of timber in construction, or the new developments in energy storage and sources cannot meet the goals written in CPR without the use of FSE. It seems that the total holistic approach may be key for future practical use of FSE - combination of probabilistic fire scenarios, scientifically based boundary data, modern simulation techniques, large data processing, and risk analysis for the evaluation of results. These features combined allow us - fire safety engineers - to shape the civil engineering development of the modern world. Moreover, citing Petroski after Rein, "(we) cannot wait for a complete scientific understanding of the phenomena we deal with, before acting to save lives" [87].

\section{REFERENCES}

[1] B.J. Meacham, "The evolution of performance-based codes and fire safety design methods", NIST-GCR-98-761, NIST, Gaithersburg, MD, 1998.

[2] B.J. Meacham, "Fire safety engineering at a crossroad", Case Stud. Fire Saf. 1, doi:10.1016/j.csfs.2013.11.001, 8-12 (2014).

[3] L. Czarnecki and D. van Gemert, "Scientific basis and rules of thumb in civil engineering: conflict or harmony?", Bull. Pol. Ac.:Tech. 64 (4), 665-673 (2016).

[4] M. Abramowicz and R. Kowalski, „Projektant konstrukcji obiektu i rzeczoznawca do spraw zabezpieczeń przeciwpożarowych - wzajemne powiązania", Materiały Budowlane, (2014), [in Polish].

[5] G. Vigne, "Origini della fire safety engineering e prospettive nella prevenzione incendi odierna", in XVI Convegno Naz. AIIA I Metod. Della Fire Saf. Eng. Alla Luce Del Codice Di Prev. Incend. 2015, Milano, 2016, [in Italian].

[6] M. Woodrow, L. Bisby, and J.L. Torero, "A nascent educational framework for fire safety engineering", Fire Saf. J. 58, doi:10.1016/j.firesaf.2013.02.004, 180-194 (2013).

[7] H.E. Nelson, "History of fire technology", in Conf. Fire Saf. Des. 21st Century, Worcester Polytechnic Institute, Worcester, MA, 1991.

[8] B.J. Meacham, "International experience in the development and use of performance-based fire safety design methods: Evolution, current situation and thoughts for the future", 6th International Symposium on Fire Safety Science, 59-76 (2000).

[9] General Services Administration, Building Fire Safety Criteria. Appendix D: Interim Guide for Goal-Oriented Systems Approach to Building Firesafety, Washington, DC, 1972.

[10] M. Law and P. Beever, "Magic numbers and golden rules", Fire Technol. 31, doi:10.1007/BF01305269, 77-83 (1995).

[11] G. V. Hadjisophocleous, N. Benichou, and A. S. Tamim, "Literature review of performance-based fire codes and design environment”, J. Fire Prot. Eng. 9, doi:10.1177/104239159800900102, 12-40 (1998).

[12] A. Alvarez, B.J. Meacham, N.A. Dembsey, and J.R. Thomas, "A framework for risk-informed performance-based fire protection design for the built environment", Fire Technol. 50, doi:10.1007/s10694-013-0366-1, 161-181 (2014).

[13] A. Alvarez, B.J. Meacham, N. Dembsey, and J. Thomas, "Twenty years of performance-based fire protection design: challenges faced and a look ahead", J. Fire Prot. Eng. 23, doi:10.1177/1042391513484911, 249-276 (2013).

[14] D.J. Thomas, "All codes are mixed: why implementation needs will prevail over "performance" and "prescription" in the open universe of 21st century fire protection", in Second Conf. Fire Saf. Des. 21st Century, pp. 227-241, Worcester Polytechnic Institute, Worcester, MA, 1999.

[15] Report of Building Committee, Recommended Practice for Arrangement of Building Codes, Washington Government Printing Office, 1925, http://hdl.handle.net/2027/uc1.\$b78828.

[16] „Ustawa z dnia 7 lipca 1994. - Prawo budowlane. Z późniejszymi zmianami”, 2016, [in Polish].

[17] „Rozporządzenie Ministra Infrastruktury z dnia 12 kwietnia 2002 r. w sprawie warunków technicznych, jakim powinny odpowiadać budynki i ich usytuowanie. $Z$ późniejszymi zmianami.”, Dz.U. 2002 Nr 75 Poz. 690, 2002, [in Polish].

[18] „Rozporządzenie Ministra Infrastruktury z dnia 17 czerwca 2011 r. w sprawie warunków technicznych, jakim powinny odpowiadać obiekty budowlane metra i ich usytuowanie", Dz.U. 2011 Nr 144 Poz. 859, 2011, [in Polish] 
[19] G. Vigne and W. Węgrzyński, "Influence of variability of soot yield parameter in assessing the safe evacuation conditions in advanced modeling analysis. Results of physical and numerical modeling comparison", in 11th Conf. Performance-Based Codes Fire Saf. Des. Methods, Warsaw, Poland, SFPE, 2016.

[20] "Regulation (EU) No 305/2011 of The European Parliament and the Council of 9th March 2011 laying down harmonised conditions for the marketing of construction products and repealing Council Directive 89/106/EEC", 5-43 (2011).

[21] S. Yokoi, "Study on the prevention of fire-spread caused by hot upward current", Report of the Building Research Institute 34, (1960).

[22] P.H. Thomas, P.L. Hinkley, C.R. Theobald, and D.L. Simms, "Investigations into the flow of hot gases in roof venting", HMSO, London, 1963.

[23] K. Kawagoe, "Real Fire and Fire Modeling", Fire Saf. Sci. - Proc. Second Int. Symp., 1-14 (1988).

[24] J.G. Quintiere and C.A. Wade, "Compartment fire modeling", in SFPE Handb. Fire Prot. Eng., pp. 981-995, doi:10.1007/978-14939-2565-0_29, Springer, New York, 2016.

[25] R.D. Peacock, G.P. Forney, P.A. Reneke, and W.W. Jones, CFAST, the Consolidated Model of Fire Growth and Smoke Transport (Version 6) Technical Reference Guide, 2009.

[26] C. Wade, G. Baker, K. Frank, A. Robbins, R. Harrison, M. Spearpoint, and C. Fleischmann, "B-RISK user guide and technical manual”, Branz Study Rep. 282, 1-38 (2013).

[27] R. Harrison, C. Wade, and M. Spearpoint, "Predicting spill plumes with the fire risk zone model B-RISK", Fire Technol. 50, doi:10.1007/s10694-013-0364-3, 205-231 (2014).

[28] L.Y. Cooper, "A concept for estimating available safe egress time in fires", Fire Saf. J. 5, doi:10.1016/0379-7112(83)9000 6-1, 135-144 (1983).

[29] W. Węgrzyński and G. Krajewski, „Dobór modeli oraz warunków brzegowych a wynik analizy numerycznej rozprzestrzeniania się dymu i ciepła”, Build. Mater. 11, (2014), [in Polish].

[30] G. Rein, J.L. Torero, W. Jahn, J. Stern-Gottfried, N.L. Ryder, S. Desanghere, M. Lázaro, F. Mowrer, A. Coles, D. Joyeux, D. Alvear, J.A. Capote, A. Jowsey, C. Abecassis-Empis, and P. Reszka, "Round-robin study of a priori modelling predictions of the Dalmarnock Fire Test One", Fire Saf. J. 44, doi:10.1016/j. firesaf.2008.12.008, 590-602 (2009).

[31] W. Jahn, G. Rein, and J.L. Torero, "A posteriori modelling of the growth phase of Dalmarnock Fire Test One", Build. Environ. 46, doi:10.1016/j.buildenv.2010.11.001, 1065-1073 (2011).

[32] K. McGrattan, S. Hostikka, R. McDermott, J. Floyd, C. Weinschenk, and K. Overholt, Fire Dynamics Simulator User's Guide, Sixth Edition, doi:10.6028/NIST.SP.1019, 2016.

[33] OpenFOAM Foundation, OpenFOAM User Guide, (n.d.). http:// cfd.direct/openfoam/user-guide/ (24 August 2016).

[34] ANSYS, ANSYS Fluent 14.5.0 - Technical Documentation, 2014.

[35] CHAM, PHOENICS Overview - CHAM Technical Report: TR 001, 2005.

[36] FSEG, Smartfire Introduction, (n.d.). http://fseg.gre.ac.uk/smartfire/index.html (accessed October 8, 2016).

[37] Siemens, Star-CCM+, n.d. http://mdx.plm.automation.siemens. com/star-ccm-plus.

[38] B. Merci, J.L. Torero, and A. Trouvé, "IAFSS working group on measurement and computation of fire phenomena", Fire Technol. 52, doi:10.1007/s10694-016-0577-3, 607-610 (2016).

[39] W. Węgrzyński, G. Krajewski, and P. Sulik, "Case study 2 - production and storage building (Poland)", in 11th Conf. Performance-Based Codes Fire Saf. Des. Methods, doi:10.13140/ RG.2.1.3677.4640, SFPE, Warsaw, 2016.
[40] P. Kubica, L. Czarnecki, S. Boroń, and W. Węgrzyński, "Maximizing the retention time of inert gases used in fixed gaseous extinguishing systems", Fire Saf. J. 80, doi:10.1016/j. firesaf.2015.11.008, 1-8 (2016).

[41] G. Krajewski and W. Węgrzyński, "Air curtain as a barrier for smoke in case of fire: Numerical modelling", Bull. Pol. Ac.: Tech. 63 (1), doi:10.1515/bpasts-2015-0016, 145-153 (2015).

[42] Z. Salamonowicz, M. Kotowski, M. Półka, and W. Barnat, "Numerical simulation of dust explosion in the spherical 201 vessel", Bull. Pol. Ac.: Tech. 63 (1), doi:10.1515/bpasts-2015-0033, 289-293 (2015).

[43] P. Tofiło, W. Węgrzyński, and R. Porowski, "Hand calculations, zone models and CFD - areas of disagreement and limits of application in practical fire protection engineering", in 11th Conf. Performance-Based Codes Fire Saf. Des. Methods, SFPE, Warsaw, Poland, 2016.

[44] Society of Fire Protection Engineers, Guidelines for Substantiating a Fire Model for a Given Application SFPE G.06, Bethesda, Maryland, 2011.

[45] K. Mcgrattan, R. Peacock, and K. Overholt, "Fire model validation - eight lessons learned", Fire Saf. Sci. - Proceedngs Elev. Int. Symp., doi:10.3801/IAFSS.FSS.11-958, 958-968 (2014).

[46] E.D. Kuligowski, R.D. Peacock, and B.L. Hoskins, Technical Note 1680 A Review of Building Evacuation Models, 2nd Edition, NIST (2010).

[47] V. Babrauskas and R. Williamson, "The historical basis of fire resistance testing - Part I", Fire Technol. 14, doi:10.1007/ BF01983053, 184-194 (1978).

[48] A. Law, "The role of modelling in structural fire engineering design”, Fire Saf. J. 80, doi:10.1016/j.firesaf.2015.11.013, 89-94 (2016).

[49] J. Stern-Gottfried, "Travelling fires for structural design”, Fire Saf. J. 54, doi:10.1016/j.firesaf.2012.06.003, 74-85 (2011).

[50] E. Rackauskaite, C. Hamel, A. Law, and G. Rein, "Improved formulation of travelling fires and application to concrete and steel structures", Structures 3, doi:10.1016/j.istruc.2015.06.001, 250-260 (2015).

[51] CEN, EN 1990:2002+A1: Eurocode-Basis of structural design, 2005.

[52] CEN, EN 1991-1-2 Eurocode 1: Actions on the structures - Part 1-2: General actions - Actions on the structures exposed to fire, 2002.

[53] P. Turkowski and P. Sulik, "Fire protection of CFRP-strengthened RC structures", in Response Struct. under Extrem. Load. Proc. Prot. 2015 Fifth Int. Work. Performance, Prot. Strength. Struct. under Extrem. Loading, pp. 789-796, East Lansing, MI, 2015.

[54] W. Węgrzyński and G. Krajewski, "Combined wind engineering, smoke flow and evacuation analysis for a design of a natural Smoke and Heat Ventilation System", Procedia Eng., (unpublished).

[55] W. Węgrzyński, "Design of smoke exhaust from a common reservoir - shaping the compartment opening for the benefits of smoke control", in 11th Conf. Performance-Based Codes Fire Saf. Des. Methods, SFPE, Warsaw, Poland, 2016.

[56] W. Węgrzyński and G. Krajewski, Systemy wentylacji pożarowej garaży. Projektowanie, ocena, odbiór, 493/2015, Instytut Techniki Budowlanej, 2015, [in Polish].

[57] P. Tofiło, R. Porowski, and W. Węgrzyński, "Spatial distribution of thermal radiation - Verification of the finite volume method", in Interflam, 2016. 
[58] A. Kolbrecki, "Model of fire spread out on outer building surface", Bull. Pol. Ac.: Tech. 63 (1), doi:10.1515/bpasts-2015-0015, 135-144 (2015).

[59] E.D. Kuligowski, "Human behavior in fire", in SFPE Handb. Fire Prot. Eng., pp. 2070-2114, doi:10.1007/978-1-4939-2565-0_58, Springer New York, New York, NY, 2016.

[60] R. Lubaś, J. Wąs, and J. Porzycki, "Cellular automata as the basis of effective and realistic agent-based models of crowd behavior", J. Supercomput. 72, doi:10.1007/s11227-016-1718-7, 2170-2196 (2016).

[61] E.D. Kuligowski, R.D. Peacock, P.A. Reneke, C.R. Hagwood, K.J. Overholt, R.P. Elkin, J.D. Averill, B.L. Hoskins, and E. Wiess, Movement on Stairs During Building Evacuations, NIST Tech. Note 1839, doi:10.1007/s10694-016-0603-5NIST, 212 (2014).

[62] K. Fridolf, K. Andrée, D. Nilsson, and H. Frantzich, "The impact of smoke on walking speed", Fire Mater. 38, doi:10.1002/ fam.2217, 744-759 (2014)

[63] E. Carattin and V. Brannigan, "Science or science fiction? The use of human behavioral models in fire safety regulation", Intersci. Comms., 553-558 (2013).

[64] E. Carattin and V. Brannigan, "Lost in abstraction : the complexity of real environments vs the assumptions of models", Fire Evacuation Model. Tech. Conf. 2014, doi:10.13140/2.1.4438.6561, (2014).

[65] V. Babrauskas, J.M. Fleming, and B. Don Russell, "RSET/ASET, a flawed concept for fire safety assessment", Fire Mater. 34, doi:10.1002/fam.1025, 341-355 (2010).

[66] BSI, The application of fire safety engineering principles to fire safety design of buildings - Part 6: Human factors: Life safety strategies - Occupant evacuation, behavious and condition (Subsystem 6), PD 7974-6. (2004).

[67] P. Grimwood and I.A. Sanderson, "A performance based approach to defining and calculating adequate firefighting water using s.8.5 of the design guide BS PD 7974:5:2014 (fire service intervention)", Fire Saf. J. 78, doi:10.1016/j.firesaf.2015.08.007, 155-167 (2015)

[68] C. Weinschenk, C. Beal, and O.A. Ezekoye, "Modeling fan-driven flows for firefighting tactics using simple analytical models and CFD", J. Fire Prot. Eng. 21, doi:10.1177/1042391510395694 85-114 (2011).

[69] Society of Fire Protection Engineers, SFPE Eng. Guide to Performance-Based Fire Protection, 2nd Ed., 2007.

[70] M.J. Hurley and E.R. Rosenbaum, "Performance-based design", in SFPE Handb. Fire Prot. Eng., pp. 1233-1261, doi:10.1007/978-1-4939-2565-0 37, Springer, New York, 2016.

[71] D.A. Purser and J.L. McAllister, "Assessment of hazards to occupants from smoke, toxic gases, and heat", in SFPE Handb. Fire Prot.Eng., pp. 2308-2428, doi:10.1007/978-1-4939-2565-0_63, Springer, New York, 2016.

[72] D.A. Purser, "Combustion toxicity", in SFPE Handb. Fire Prot. Eng., pp. 2207-2307, doi:10.1007/978-1-4939-2565-0 62, Springer, New York, 2016.
[73] T. Yamada and Y. Akizuki, "Visibility and human behavior in fire smoke", in SFPE Handb. Fire Prot. Eng., pp. 2181-2206. doi:10.1007/978-1-4939-2565-0_61, Springer, New York, 2016.

[74] W. Węgrzyński and P. Turkowski, "Fire resistance of a roof tensile structure in parametric fire conditions calculated using CFD simulations and simplified calculation methods", in SFPE Eur. Conf. Fire Saf. Eng., doi:10.13140/RG.2.1.1832.7286, (2015).

[75] S. Hostikka and O. Keski-Rahkonen, "Probabilistic simulation of fire scenarios", Nucl. Eng. Des. 224, doi:10.1016/ S0029-5493(03)00106-7, 301-311 (2003).

[76] P. Ayala, A. Cantizano, E.F. Sánchez-Úbeda, and C. Gutiérrez-Montes, "The use of fractional factorial design for atrium fires prediction", Fire Technol., doi:10.1007/s10694-016-0609-z, (2016).

[77] S. Suard, S. Hostikka, and J. Baccou, "Sensitivity analysis of fire models using a fractional factorial design", Fire Saf. J. 62, doi:10.1016/j.firesaf.2013.01.031, 115-124 (2013).

[78] G. Baker, C. Wade, M. Spearpoint, and C. Fleischmann, "Developing probabilistic design fires for performance-based fire safety engineering", Procedia Eng. 62, doi:10.1016/j. proeng.2013.08.109, 639-647 (2013).

[79] J. Hietaniemi and E. Mikkola, Design Fires for Fire Safety Engineering, 2010.

[80] A. Bwalya, "An overview of design fires for building compartments", Fire Technol. 44, doi:10.1007/s10694-007-0031-7, 167-184 (2008).

[81] H. Park, B.J. Meacham, N.A. Dembsey, and M. Goulthorpe, "Conceptual model development for holistic building fire safety performance analysis", Fire Technol. 51, doi:10.1007/ s10694-013-0374-1, 173-193 (2013).

[82] J. Gałaj, W. Jaskółowski, M. Konecki, P. Tofiło, and N. Tuśnio, "Interactive modular platform for fire risk assessment of buildings as a supporting tool for buildings and infrastructures design", Procedia Eng. 57, doi:10.1016/j.proeng.2013.04.042 310-319 (2013).

[83] P. Tofiło, M. Konecki, J. Gałaj, W. Jaskółowski, N. Tuśnio, and M. Cisek, "Expert system for building fire safety analysis and risk assessment", Procedia Eng. 57, doi:10.1016/j. proeng.2013.04.146, 1156-1165 (2013).

[84] H. Park, "Development of a holistic approach to integrate fire safety performance with building design", Worcester Polytechnic Institute, 2014.

[85] W. Węgrzyński, "Fire testing laboratory in performance based engineering", in 11th Conf. Performance-Based Codes Fire Saf. Des. Methods, doi: 10.13140/RG.2.1.3368.2168, Pionki, 2016.

[86] J. Kinowski, B. Sędłak, and P. Sulik, "Falling parts of external walls claddings in case of fire - ITB test method - results comparison", MATEC Web Conf. 46, doi:10.1051/matecconf/20164602005, (2016).

[87] G. Rein, "Trends in fire protection engineering: Challenges of today and tomorrow", in Symp. Fire Prot. a Chang. World, NFPA, Munich, 2016. 